\title{
Development of Student Learning Worksheet Based on Discovery Learning to Improve Understanding of Animal Life Cycle Concept
}

\section{Pengembangan Lembar Kerja Siswa Berbasis Discovery Learning untuk Meningkatkan Pemahaman Konsep Daur Hidup Hewan}

\author{
Wijianti ${ }^{1}$, Wahidmurni ${ }^{2}$ \\ 1,2 Universitas Islam Negeri Maulana Malik Ibrahim Malang \\ 1Wijianti25.wa@gmail.com, 2Wahidmurni@pips.uin-malang.ac.id
}

\begin{abstract}
The purpose of this research is to develop a Student Learning Worksheet (LKS) based on discovery learning to improve the understanding of the concept of animal life cycle material in Grade IV Madrasah Ibtidiyah students, including: describing product specifications, explaining the level of product attractiveness, and explaining the difference in the level of understanding of student concepts from those learn by using LKS and not using LKS. The subjects of the study were the fourth grade students of MI Sunan Ampel Pakis. The research procedure follows five stages of the ten stages developed by Borg and Gall in the framework of developing modules of the research and development method. The five stages are research and information collecting, planning, developing preliminary forms of product, preliminary field testing, and playing product revision. Logical feasibility analysis of media worksheets using validation of material experts, linguists, design experts and subject matter experts; the attractiveness of student worksheets was empirically analyzed using a closed questionnaire of student responses, and differences in the level of understanding were analyzed through the $t$ test of the pre test results before using the media and the post test results after using the media in the experimental class and the control class. The results showed that the worksheets produced were feasible to use with the predicate of validation both in terms of design, language, and learning, as well as very good in terms of material; Student responses also show a very interesting predicate; the level of concept understanding of students who learn to use LKS is better than those who do not use LKS. This indicates that the worksheets developed can be used to be applied in the next research phase.
\end{abstract}

Keywords: Student Worksheets: Discovery Lerning Based Worksheet: Animal Life Cycle; Concept Understanding

Abstrak: Tujuan penelitian adalah mengembangkan Lembar Kerja Siswa (LKS) berbasis discovery
learning untuk meningkatkan pemahaman konsep materi daur hidup hewan pada siswa kelas IV
Madrasah Ibtidiyah, mencakup: mendeskripsikan spesifikasi produk, menjelaskan tingkat
kemenarikan produk, dan menjelaskan perbedaan tingkat pemahaman konsep siswa dari yang
belajar dengan menggunakan LKS dan tidak menggunakan LKS. Subjek penelitian adalah siswa
kelas IV MI Sunan Ampel Pakis. Prosedur penelitian mengikuti lima tahapan dari sepuluh
tahapan yang dikembangkan oleh Borg and Gall dalam rangka pengembangan modul dari
metode research and development. Lima tahapan tersebut adalah research and information collecting,
planning, develop preliminary form of product, preliminary field testing, dan main product revision.
Analisis kelayakan media LKS secara logis dengan menggunakan validasi ahli materi, ahli
bahasa, ahli desain dan ahli mata pelajaran; kemenarikan LKS secara empiris dianalisis dengan
menggunakan kuesioner tertutup tanggapan siswa, dan perbedaan tingkat pemahaman
dianalisis melalui uji t dari hasil pre test sebelum menggunakan media dan hasil post test setelah
menggunakan media pada kelas eksperimen dan kelas kontrol. Hasil penelitian menunjukkan
bahwa LKS yang dihasilkan layak digunakan dengan predikat validasi baik dari sisi desain,
bahasa, dan pembelajaran, serta sangat baik dari sisi materi; tanggapan siswa juga menunjukkan
predikat sangat menarik; tingkat pemahaman konsep siswa yang belajar menggunakan LKS 
lebih baik dari yang tidak menggunakan LKS. Ini mengindikasi bahwa LKS yang dikembangkan dapat digunakan untuk diterapkan pada fase penelitian selanjutnya.

Kata Kunci: Lembar Kerja Siswa: LKS Berbasis Discovery Lerning; Daur Hidup Hewan; Pemahaman Konsep.

Received : 06-06-2020

Revised : 10-07-2020

Approved : 10-07-2020

Published : 20-07-2020

Copyright (C) Madrasah Jurnal Pendidikan dan Pembelajaran Dasar. All Right Reserved.

This is an open access article under the CC BY-NC-ND license

(http://creativecommons.org/licenses/by-nc-nd/4.0/).

Correspondence Address: ${ }^{2}$ Wahidmurni@pips.uin-malang.ac.id

\section{A. PENDAHULUAN}

Pembelajaran Ilmu Pengetahuan Alam (IPA) berkaitan dengan cara mencari tahu tentang alam secara sistematis, sehingga IPA bukan hanya penugasan kumpulan pengetahuan berupa fakta-fakta, konsep-konsep atau prinsip-prinsip saja tetapi juga merupakan proses. Pendidikan IPA diharapkan dapat menjadi wahana bagi peserta didik untuk mempelajari diri dan alam sekitar, serta prospek pengembangan lebih lanjut dalam menerapkannya di dalam kehidupan sehari-hari. Proses pembelajaran mata pelajaran IPA di SD/MI menekankan pada pemberian pengalaman langsung untuk mengembangkan kompetensi agar menjelajahi dan memahami alam sekitar secara ilmiah. Pendidikan IPA diarahkan untuk mencari tahu dan berbuat sehingga dapat membantu peserta didik untuk memperoleh pemahaman yang lebih mendalam tentang alam sekitar.

Rumusan kompetensi lulusan satuan pendidikan SD/MI dalam aspek pengetahuan diharapkan siswa memiliki pengetahuan faktual, konseptual, prosedural, dan metakognitif pada tingkat dasar berkenaan dengan: 1. ilmu pengetahuan, 2 . teknologi, 3. seni, dan 4. budaya. Mampu mengaitkan pengetahuan di atas dalam konteks diri sendiri, keluarga, sekolah, masyarakat dan lingkungan alam sekitar, bangsa, dan negara. Untuk itu dalam perolehannya siswa hendaknya melakukan kegiatan prosedural dengan cara melakukan sesuatu atau kegiatan yang berkenaan dengan ilmu pengetahuan, teknologi, seni, dan budaya terkait dengan diri sendiri, keluarga, sekolah, masyarakat dan lingkungan alam sekitar, bangsa dan negara. Berkenaan dengan pembelajaran IPA di SD/MI salah satu mandat yang dituangkan dalam Standar Isi Kurikulum 2013 dalam rumusan kompetensi yang harus dikuasai siswa SD/MI ketika belajar IPA antara lain melakukan pengamatan objek IPA dengan menggunakan panca indra dan alat sederhana (Peraturan Menteri Pendidikan dan Kebudayaan Nomor 21 Tahun 2016).

Kegiatan mengamati sebagai kegiatan pertama dalam pendekatan saintifik sebelum menanya, mencoba, menalar dan mengkomunikasikan mengandung makna penggunaan seluruh panca indra dalam aktivitas belajar. Mengamati menggunakan indra mata dilakukan dengan cara melihat, membaca, menonton; mengamati menggunakan indra hidung/penciuman dilakukan dengan membaui; mengamati dengan indra lidah dilakukan dengan mengecap/merasakan; mengamati dengan indra telinga dilakukan dengan mendengar, menyimak; dan mengamati dengan menggunakan indra kulit dilakukan dengan meraba, merasakan cuaca misalnya, dan sebagainya (Wahidmurni, 2017:153). 


\section{MADRASAH}

Jurnal Pendidikan dan Pembelajaran Dasar

p ISSN: 1979-5599 | e ISSN: 2502-194X

P a g e | $\mathbf{1 7}$

Dengan demikian, wajib bagi seorang guru untuk memfasilitasi kegiatan belajar siswa yang memungkinkan mereka melakukan kegiatan pengamatan secara langsung. Peserta didik tidak hanya paham secara teori tapi juga terlibat dalam kondisi nyata yang ada di sekitarnya. Guru wajib memberikan kesempatan kepada peserta didik untuk berinteraksi langsung dengan obyek belajar, sebagai contoh melakukan pengamatan atau suatu percobaan sehingga menghasilkan penemuan baru dan pengalaman baru bagi peserta didik.

Ruang lingkup kompetensi inti pengetahuan mata pelajaran IPA SD/MI secara garis besar terinci menjadi tujuh kompetensi dengan materi mencakup: (1) hubungan antara bentuk dan fungsi bagian tubuh pada hewan dan tumbuhan, (2) siklus hidup beberapa jenis makhluk hidup serta mengaitkan dengan upaya pelestariannya, (3) macam-macam gaya, antara lain: gaya otot, gaya listrik, gaya magnet, gaya gravitasi, dan gaya gesekan, (4) gaya dengan gerak pada peristiwa di lingkungan sekitar, (5) sumber energi, perubahan bentuk energi, dan sumber energi alternatif (angin, air, matahari, panas bumi, bahan bakar organik, dan nuklir) dalam kehidupan sehari hari, (6) sifat-sifat bunyi dan keterkaitannya dengan indera pendengaran, dan (7) sifat-sifat cahaya dan keterkaitannya dengan indera penglihatan dan (8) pentingnya upaya keseimbangan dan pelestarian sumber daya alam di lingkungannya (Permendikbud Nomor 37 Tahun 2018).

Salah satu tujuan pembelajaran adalah siswa diwajibkan untuk memahami hewan beserta proses kehidupannya atau sering disebut daur hidup hewan, yaitu diklasifikasikan antara yang mengalami metamorfosis dan tidak mengalami metamorfosis. Untuk mencapai tujuan ini diharapkan siswa harus belajar dengan mengamati secara langsung bagaimana daur hidup hewan seperti kupu-kupu, belalang, ayam dan sebagainya. Hal semacam ini tidak terjadi pada kelas yang teramati. Pada kenyataannya, siswa tidak diberikan kesempatan secara langsung untuk melakukan pengamatan terhadap peristiwa daur hidup hewan. Hal demikian juga untuk menghindari fenomena sebagaimana dilaporkan Sukamti dan Untari (2018) yang menunjukkan bahwa terdapat ketidaksesuaian materi ajar yang ada dalam buku pegangan siswa dan buku pegangan guru, sehingga mempengaruhi perbedaan penilaian pembelajaran. Untuk kepentingan inilah guru mempunyai kewajiban untuk menyesuaikan materi yang ada, sehingga program penilaian yang dikembangkan sesuai dengan tujuan pembelajaran yang ditetapkan

Kenyataan yang ditemukan di Madrasah Ibtidaiyah (MI) Sunan Ampel bahwa media yang digunakan dalam proses pembelajaran masih sangat minim, seperti papan tulis, buku paket, dan sekali-kali menggunakan gambar yang dicetak sendiri, tersedia LCD tetapi tidak dapat digunakan secara optimal, sehingga pengalaman siswa secara langsung untuk mengenal alam sekitar masih dirasakan kurang. Seharusnya pembelajaran untuk tingkat anak sekolah dasar perlu menggunakan media pembelajaran yang menarik untuk siswa, karena pada dasarnya pada usia sekolah dasar siswa sangat senang dengan suasana bermain dan hal-hal yang bersifat kongkret. Kenyataan ini senada dengan temuan Sari (2013) bahwa permasalahan pembelajaran Sains terjadi dikarenakan pembelajarannya tidak dilakukan sebagaimana mestinya dan rendahnya kualitas mengajar guru.

Dalam praktiknya metode pembelajaran yang digunakan sebagian besar masih ceramah dan penugasan tetapi kurang memberikan kesempatan siswa untuk mengalami secara langsung. Hal demikian tentunya kurang maksimal dalam melaksanakan 
pendekatan saintifik dalam program pembelajaran, sebagaimana dianjurkan dalam pelaksanaan Kurikulum 2013, khususnya tentang standar proses pendidikan dasar dan menengah (Permendikbud No. 65 tahun 2013). Hal demikian menjadikan siswa menjadi kurang antusias dalam belajar dan berpartisipasi dalam menemukan pengetahuan. Hal ini bertentangan dengan tujuan pembelajaran IPA yaitu mengembangkan rasa ingin tahu, mengembangkan keterampilan proses untuk menyelidiki alam sekitar, memecahkan masalah dan membuat keputusan, meningkatkan kesadaran untuk menghargai alam dan segala keteraturannya sebagai salah satu ciptaan Tuhan.

Berdasar kenyataan ini diperlukan pengembangan LKS berbasis discovery learning untuk meningkatkan pemahaman konsep daur hidup hewan pada siswa kelas IV Madrasah Ibtidiyah, untuk mencapai kompetensi membandingkan siklus hidup beberapa jenis makhluk hidup serta mengaitkan dengan upaya pelestariannya. LKS yang dikembangkan diharapkan dapat membantu siswa menguasai tujuan dan terlibat aktif dalam pembelajaran. Potensi keberhasilan LKS sangat besar dalam pencapaian tujuan pembelajaran. Hal ini sebagaimana ditunjukkan oleh Fannie dan Rohati (2014) bahwa proses pembelajaran dapat berjalan dengan baik dan dapat meningkatkan hasil pembelajaran jika dalam mata pelajaran disediakan LKS yang berkualitas. Untuk itu, mereka menyarankan agar para peneliti (guru) dapat mengembangkan LKS dengan basis yang beragam, sehingga dapat memotivasi para siswa dalam belajar. Hal demikian sebagaimana dilaporkan Hanim dkk. (2017) bahwa untuk meningkatkan hasil belajar siswa dapat digunakan LKS berbasis ketrampilan proses sains. Interaksi dalam belajar dengan menggunakan lembar kerja siswa dan motivasi belajar berpengaruh positif signifikan terhadap hasil belajar.

Pengembangan LKS berbasis Discovery Learning dipilih untuk memecahkan masalah secara intensif di bawah pengawasan guru. Discovery Learning merupakan metode pembelajaran kognitif yang menuntun guru lebih kreatif menciptakan situasi yang dapat membuat peserta didik belajar aktif menemukan pengetahuan sendiri (Mulyatiningsih, 2012). LKS, memudahkan bagi seorang pendidik untuk melengkapi materi yang tidak dapat disampaikan langsung kepada peserta didik. Sedangkan bagi peserta didik membantu untuk menerapkan dan mengintegrasikan berbagai konsep yang telah ditemukan, membantu memahami materi dan menemukan suatu konsep (Prastowo, 2014).

\section{B. METODE PENELITIAN}

Penelitian dan pengembangan LKS Berbasis Discovery Learning materi daur hidup hewan dilakukan dengan menerapkan lima tahapan dari sepuluh tahapan pengembangan produk Borg and Gall (1983). Lima tahapan sebagai langkah menghasilkan media LKS sebelum diuji cobakan pada lapangan yang lebih besar adalah research and development. Lima tahapan tersebut adalah research and information collecting, planning, develop preliminary form of product, preliminary field testing, dan main product revision. Subjek uji coba adalah siswa kelas IV A dan IV B MI Sunan Ampel Pakis Malang masing-masing kelas berisi 24 orang siswa. Kelima tahapan penelitian dipilih dikarenakan penelitian ini masih dalam awal pengembangan LKS, sampai dihasilkan LKS yang benar-benar layak menurut validator secara logis dan guru serta siswa pada kelas terbatas. Hasil dari tahapan awal ini sebagai dasar untuk dikembangkan lebih lanjut pada tahapan keenam dengan mengujicobakan pada kelas besar sampai dihasilkan LKS yang layak untuk didesiminasikan dalam skala yang lebih luas. Dengan demikian, 


\section{MADRASAH}

Jurnal Pendidikan dan Pembelajaran Dasar

p ISSN: 1979-5599 | e ISSN: 2502-194X

Pag e | 19

hasil penelitian dapat ditindaklanjuti dengan penelitian berikutnya dengan menerapkan langkah ke enam sampai dengan langkah kesepuluh.

Instrumen pengumpulan data yang digunakan adalah kuesioner penilaian kelayakan butir secara logis/rasional dari masing-masing validator, dimana masingmasing instrumen kelayakan dinilai oleh seorang dosen sesuai dengan keahliannya. Penilaian kelayakan media ditinjau dari isi materi yang divalidasi oleh dosen matakuliah Pendidikan IPA. Penyajian bahasa divalidasi oleh dosen Bahasa Indonesia dan telah berpengalaman dalam mengembangkan media pembelajaran. Penyajian media dari sisi desain dan pembelajaran divalidasi oleh dosen dengan latar belakang pendidikan doktor teknologi pembelajaran. Pengambilan kesimpulan kelayakan media pembelajaran dari segi isi materi, desain, bahasa serta pembelajaran menggunakan kriteria tabel B.1.

Tabel B.1. Kriteria Kelayakan dan Revisi Produk

\begin{tabular}{ll}
\hline Prosentase $(\%)$ & Kriteria Kelayakan Produk \\
\hline $90-100$ & Sangat baik, tidak perlu ada revisi \\
\hline $75-89$ & Baik, tidak perlu ada revisi \\
\hline $65-74$ & Cukup baik, perlu direvisi \\
\hline $55-64$ & Kurang baik, perlu direvisi \\
\hline$<55$ & Sangat kurang baik, perlu revisi semua \\
\hline
\end{tabular}

Sumber: Sudjana (1995)

Data kuesioner dianalisis secara statistik deksriptif unttuk menentukan rerata validitas LKS dari aspek isi materi, desain, bahasa dan pembelajaran; sementara Uji T tes digunakan untuk menentukan ada dan tidaknya perbedaan tingkat pemahaman konsep materi daur hidup hewan siswa yang belajar dengan menggunakan LKS Berbasis Discovery Learning dan tidak menggunakan LKS Berbasis Discovery Learning. Adapun desain penelitian disajikan dalam gambar 1 .

Gambar B.1. Pretest-Posttest Control Group Design

\begin{tabular}{llll} 
R1 & $\mathrm{O} 1$ & $\mathrm{X}$ & $\mathrm{O} 2$ \\
$\mathrm{R} 2$ & $\mathrm{O} 3$ & & $\mathrm{O} 4$ \\
\hline
\end{tabular}

R1 adalah kelompok eksperimen, R2 adalah kelompok kontrol, X adalah perlakuan, O1 dan $\mathrm{O} 3$ adalah pretest, dan $\mathrm{O} 2$ dan $\mathrm{O} 4$ adalah posttest. Data yang di analisis adalah skor pre test dan post test dari kelas eksperimen dan kelas kontrol dengan menggunakan formula T-Test (Pretes-Postes) Uji Beda Dua Mean Independent secara manual.

\section{HASIL DAN PEMBAHASAN}

\section{Proses Penyusunan Media LKS Berbasis Discovery Learning}

Hasil penelitian pada langkah pertama dalam pengembangan media LKS, yakni research and information colleting. Dalam tahap ini dilakukan pengkajian kurikulum yang meliputi KI, KD, Indikator dan mata pelajaran. Dilanjutkan dengan studi lapangan guna mengidentifikasi karakteristik siswa MI Sunan Ampel khususnya kelas IV, kesulitan 
belajar dan kebutuhan media yang cocok untuk diterapkan di MI Sunan Ampel. Kegiatan ini diperoleh dengan pengamatan langsung saat pembelajaran dan wawancara kepada wali kelas IV. Kedua adalah pengumpulan data dan pemilihan bahan. Dalam tahap ini dilakukan pengumpulan materi dari referensi beberapa buku dan internet, tentunya disesuaikan dengan materi yang diambil yaitu daur hidup hewan.

Langkah kedua yaitu planning. Merencanakan penyusunan media berdasarkan langkah pertama. Media yang dikembangkan adalah LKS. Dalam LKS dicantumkan materi metamorfosis hewan secara lengkap, detail dan sistematis. Karena LKS ini berbasis discovery learning maka banyak percobaan atau pengamatan yang dilakukan oleh siswa. Ini sesuai dengan tujuan pembelajaran IPA yang menghendaki siswa terlibat dalam kegiatan percobaan atau pengamatan untuk menemukan suatu konsep. Selanjutnya, diberikan variasi dalam LKS, seperti korelasi dengan pengetahuan agama dan juga keterampilan. Untuk finishing yaitu tahap desain LKS, pada tahap ini memperhatikan beberapa point diantaranya pemilihan huruf, penggunaan gambar, dan pemilihan warna. Dengan desain yang menarik diharapakan meningkatkan minat siswa dalam mempelajari materi melalui LKS ini.

Langkah ketiga yaitu develop preliminary form of product. Produk atau media yang telah dibuat diuji validitasnya kepada ahli isi materi, desain, bahasa dan pembelajaran. Hasil uji validasi menunjukkan bahwa dari sisi materi tergolong sangat baik dengan rerata sekor $92 \%$, dari sisi desain tergolong baik dengan rerata sekor $84 \%$, dari sisi bahasa tergolong baik dengan rerata sekor $80 \%$, dari sisi pembelajaran tergolong baik dengan rerata sekor $84 \%$. Adapun rincian penilaian dari masing-masing butir disajikan dalam tabel 2 sampai dengan tabel 5.

Tabel C.1. Tingkat Validasi Isi Materi

\begin{tabular}{clcl}
\hline No & Indikator & Skor Rata-Rata & Keputusan Uji \\
\hline 1 & Relevansi media dengan kurikulum & $100 \%$ & Sangat Baik \\
\hline 2 & Kesesuaian materi dengan KI & $80 \%$ & Baik \\
\hline 3 & Kesesuaian materi dengan SK & $80 \%$ & Baik \\
\hline 4 & Kesesuaian materi dengan tujuan & $100 \%$ & Sangat Baik \\
\hline 5 & Kesesuaian materi dengan media & $100 \%$ & Sangat Baik \\
\hline 6 & Kualitas soal pada LKS & $80 \%$ & Baik \\
\hline 7 & Kesesuaian soal dengan materi & $80 \%$ & Baik \\
\hline 8 & Kedalaman materi & $80 \%$ & Baik \\
\hline 9 & Keruntutan materi & $100 \%$ & Sangat Baik \\
\hline 10 & Media meningkatkan pemahaman & $100 \%$ & Sangat Baik \\
\hline 11 & Kemenarikan LKS & $100 \%$ & Sangat Baik \\
\hline 12 & Motivasi siswa giat belajar & $100 \%$ & Sangat Baik \\
\hline & Rata-Rata & $92 \%$ & Sangat Baik \\
\hline
\end{tabular}

Tabel C.2. Tingkat Validasi Desain

\begin{tabular}{clcl}
\hline No & \multicolumn{1}{c}{ Indikator } & Skor rata-rata & Keputusan uji \\
\hline 1 & Kemanarikan model desain & $80 \%$ & Baik \\
\hline 2 & Kesesuaian gambar & $80 \%$ & Baik \\
\hline 3 & Desain pewarnaan & $80 \%$ & Baik \\
\hline 4 & Ketepatan penempatan gambar & $80 \%$ & Baik \\
\hline
\end{tabular}




\section{MADRASAH}

Jurnal Pendidikan dan Pembelajaran Dasar

p ISSN: 1979-5599 | e ISSN: 2502-194X

P a g e | 21

\begin{tabular}{clcl}
\hline No & \multicolumn{1}{c}{ Indikator } & Skor rata-rata & Keputusan uji \\
\hline 5 & Jenis huruf & $80 \%$ & Baik \\
\hline 6 & Ketepatan gambar cover & $100 \%$ & Sangat Baik \\
\hline 7 & Kemenarikan desian cover & $100 \%$ & Sangat Baik \\
\hline 8 & Variasi jenis ukuran \& bentuk huruf & $80 \%$ & Baik \\
\hline 9 & Kejelasan tulisan & $80 \%$ & Baik \\
\hline 10 & Kemenarikan gambar materi & $80 \%$ & Baik \\
\hline & Rata-Rata & $84 \%$ & Baik \\
\hline
\end{tabular}

Tabel C.3. Tingkat Validasi Bahasa

\begin{tabular}{clcl}
\hline No & \multicolumn{1}{c}{ Indikator } & Skor rata-rata & Keputusan Uji \\
\hline 1 & Pemilihan kosa kata & $80 \%$ & Baik \\
\hline 2 & Kejelasan ejaan & $80 \%$ & Baik \\
\hline 3 & Kejelasan struktur kalimat & $80 \%$ & Baik \\
\hline 4 & Ketepatan tanda baca & $80 \%$ & Baik \\
\hline 5 & Ketepatan jenis huruf & $80 \%$ & Baik \\
\hline 6 & Ketepatan layout pengetikan & $80 \%$ & Baik \\
\hline 7 & Konsistensi bahasa percakapan & $80 \%$ & Baik \\
\hline 8 & Konsistensi spasi & $80 \%$ & Baik \\
\hline 9 & Ketepatan penataan teks & $80 \%$ & Baik \\
\hline 10 & Kejelasan pengetikan & $80 \%$ & Baik \\
\hline 11 & Kemudahan bahasa & $80 \%$ & Baik \\
\hline 12 & Kejelasan bahasa & $80 \%$ & Baik \\
\hline & Rata-Rata & $80 \%$ & Baik
\end{tabular}

Tabel C.4. Tingkat Validasi Pembelajaran

\begin{tabular}{clcl}
\hline No & \multicolumn{1}{c}{ Indikator } & Skor rata-rata & Keputusan uji \\
\hline 1 & Memudahkan pengajaran & $80 \%$ & Baik \\
\hline 2 & Media yang menyenangkan & $80 \%$ & Baik \\
\hline 3 & Media yang mengaktifkan siswa & $80 \%$ & Baik \\
\hline 4 & Ketepatan jenis \& ukuran huruf & $100 \%$ & Sangat Baik \\
\hline 5 & Kejelasan materi \& gambar & $80 \%$ & Baik \\
\hline 6 & Meningkatkan pemahaman siswa & $80 \%$ & Baik \\
\hline 7 & Kesesuaian media dengan materi & $100 \%$ & Sangat Baik \\
\hline 8 & Kesesuaian media dengan tujuan & $80 \%$ & Baik \\
\hline 9 & Memotivasi siswa & $80 \%$ & Baik \\
\hline 10 & Menarik bagi siswa & $80 \%$ & Baik \\
\hline & Rata-Rata & $84 \%$ & Baik \\
\hline
\end{tabular}

Langkah keempat yaitu preliminary field testing. Pada tahap ini dilakukan uji coba produk terhadap 2 kelas, yaitu kelas kontrol dan kelas eksperimen. Pada kelas kontrol atau yang tidak diimpelementasikan produk memperoleh sekor pre test sebesar 51,67 dan post tes sebesar 66,25 . Sedangkan hasil pretes dan post tes kelas ekperimen atau kelas yang diimplementasikan media LKS memproleh sekor pre tes sebesar 55,22 dan 
post tes sebesar 86,88 . Adapun dari sisi kemenarikan LKS bagi siswa menunjukan hasil rerata skor sebesar $97 \%$ atau dengan predikat sangat menarik. Secara terperinci rerata dari masing-masing indikator kemenarikan disajikan pada tabel 6 .

Tabel C.6. Tingkat Kemenarikan Media LKS

\begin{tabular}{clcl}
\hline No & \multicolumn{1}{c}{ Indikator } & Skor rata-rata & Keputusan uji \\
\hline 1 & Tampilan media & $98 \%$ & Sangat menarik \\
\hline 2 & Kesesuaian materi dengan media & $91 \%$ & Sangat menarik \\
\hline 3 & LKS mudah dipahami & $98 \%$ & Sangat menarik \\
\hline 4 & Tulisan jelas & $100 \%$ & Sangat menarik \\
\hline 5 & Pembelajaran yang menyenangkan & $100 \%$ & Sangat menarik \\
\hline 6 & Termotivasi belajar & $97 \%$ & Sangat menarik \\
\hline 7 & Aktif dalam pembelajaran & $98 \%$ & Sangat menarik \\
\hline & Rata-Rata & $97 \%$ & Sangat menarik \\
\hline
\end{tabular}

Berdasar respons atau tanggapan siswa terhadap kemenarikan LKS dan besaran selisih hasil posttest dikurangi pretest kelas eksperimen sebesar 31,66 lebih tinggi dibandingkan dengan siswa yang tidak menggunakan LKS atau kelas kontrol dengan selisih hasil posttest dikurangi pretest sebesar 14,58. Hasil ini mendukung teori dan temuan penelitian yang menyatakan Hasil penelitian Vallusova (2013) dengan menggunakan lembar kerja, partisipasi kelas, fokus pada cerita terbukti berkontribusi pada partisipasi siswa yang lebih tinggi. Secara tidak langsung mengarah pada aturan yang lebih jelas selama pelajaran. Guru mengetahui apa yang diharapkan dari siswa, dan siswa tahu apa yang diharapkan dari guru. Ini berkontribusi pada suasana yang menyenangkan dan kooperatif serta meminimalisir hambatan komunikasi antara guru dan siswa. Prastowo (2014) bahwa fungsi LKS pada pembelajaran tematik yaitu mempermudah peserta didik, meminimalkan peran pendidik, bahan ajar untuk berlatih serta mempermudah proses pembelajaran.

Langkah kelima yakni main product revision. Melakukan revisi produk berdasarkan saran validator. Hal ini dilakukan dengan tujuan kesempurnaan media yang dikembangkan sehingga penggunaaan uji coba kelas besar lebih optimal.

\section{Dampak penggunaan media LKS Berbasis Discovery Learning terhadap Tingkat Pemahaman Konsep Siswa}

Pengujian hipotesis ini menggunakan uji $\mathrm{T}$ (uji beda), pengujian ini ditujukan untuk menjelaskan keefektifan media LKS Berbasis Discovery Learning untuk meningkatkan pemhahaman konsep materi daur hidup hewan pada siswa kelas IV. Analisis uji $\mathrm{T}$ dilakukan secara manual dengan hasil $\mathrm{T}$ hitung sebesar 6,12 sedangkan $\mathrm{t}$ tabel sebesar 1,714. Oleh karena $\mathrm{t}$ hitung lebih besar dari $\mathrm{t}$ tabel, maka Hipotesis penelitian yang menyatakan bahwa "tingkat pemahaman konsep siswa kelas IV yang belajar dengan menggunakan LKS berbasis discovery learning lebih baik daripada tingkat pemahaman konsep siswa yang belajar tanpa menggunakan LKS berbasis discovery learning", terbukti mendapat dukungan empiris. Hasil ini mendukung berbagai temuan penelitian tentang pemanfaatan LKS dengan berbagai variasi perlakuan, seperti temuan Pertiwi dkk. (2017) menunjukkan bahwa LKS yang dikembangkan terbukti efektif dalam meningkatkan hasil belajar siswa dan meningkatkan ketrampilan berpikir siswa. Irfana et al., (2019) menunjukkan bahwa lembar kerja peserta didik terbukti mampu 


\section{MADRASAH}

Jurnal Pendidikan dan Pembelajaran Dasar

p ISSN: 1979-5599 | e ISSN: 2502-194X

P a g e | 23

meningkatkan kemampuan berpikir kreatif dalam aspek kelancaran, keluwesan, elaborasi, dan keaslian yang ditunjukkan oleh peningkatan skor belajar.

Secara khusus bukti keberhasilan LKS dalam pembelajaran IPA yang mendapat dukungan penelitian ini antara lain temuan Kusumawati (2017) bahwa hasil belajar macam-macam energi siswa kelas IV Sekolah Dasar dapat ditingkatkan melalui pengembangan LKS dengan menggunakan pendekatan saintifik. Shalikhah (2015) menunjukkan bahwa ketrampilan sains IPA kelas ekperimen lebih tinggi dari pada ketrampilan sains IPA kelas kontrol. Syawaludin et al., (2017) bahwa hasil uji coba LKS IPA berbasis model POE yang dilakukan pada tiga sekolah dasar menunjukkan bahwa LKS tersebut layak untuk digunakan. Winahyu et al., (2017) pengunaan LKS berbasis saintifik terbukti mampu meningkatkan sains siswa dan kesan siswa belajar menjadi lebih menyenangkan dan mereka berharap ada kegiatan percobaan lagi. Susilowati (2014) menyatakan bahwa belajar IPA merupakan belajar menemukan melalui proses sains, bukan sekedar belajar menghafal konsep. Untuk itulah pendekatan saintifik dalam kurikulum 2013 sangat relevan untuk diaplikasikan. Windiastuti et al., (2018) LKS yang dikembangkan berbasis inkuiri terbimbing terbukti valid, praktis dan efektif untuk mendukung pembelajaran materi pembelajaran Biologi.

Temuan penelitian juga memperkuat temuan Temuan Celikler dan Aksan (2012) yang menunjukkan bahwa lembar kerja memungkinkan siswa untuk lebih aktif dan berhasil meningkatkan partisipasinya di kelas; penggunaan lembar kerja memberikan pengalaman belajar menjadi lebih bermakna dan membangun minat untuk mengikuti mata pelajaran. Dukungan terhadap berbagai temuan penelitian sebelumnya, mengindikasikan pentingnya peran LKS dalam meningkatkan kualitas dan hasil pembelajaran siswa.

\section{KESIMPULAN DAN SARAN}

Proses penyusunan pengembangan media LKS berbasis discovery learning untuk meningkatkan pemahaman konsep materi daur hidup hewan pada kelas IV mengikuti tahapan dari Borg and Gall (1983) dengan menerepakan lima tahapan yakni: Tahapan pertama dengan mengumpulkan informasi dan penelitian awal ditemukan kurangnya media yang memadai untuk pembelajaran IPA khususnya materi daur hidup hewan berikut bahan ajarnya. Tahapan yang kedua, melakukan perencanaan penyusunan media LKS dengan mengacu pada kurikulum 2013 yang meliputi KI, KD, dan indikator yang sesuai. Tahapan yang ketiga, media LKS berbasis discovery learning dilakukan penilaian dari sisi isi materi, desain, bahasa serta pembelajaran. Hasil validasi media LKS dinyatakan layak digunakan dengan hasil penilaian dalam katagori baik, bahkan dari sisi materi hasil penilaiannya sangat baik. Tahapan yang keempat, melakukan uji coba media LKS pada 2 kelas, dengan rincian satu kelas sebagai kelas kontrol dan satu kelas sebagai kelas eksperimen.

Hasil uji beda menunjukkan bahwa tingkat pemahaman konsep siswa yang belajar dengan menggunakan media LKS Berbasis discovery larning lebih tinggi daripada tingkat pemahaman konsep siswa yang belajar tanpa menggunakan media LKS Berbasis discovery larning. Hasil penelitian ini mengindikasikan pentingnya peran LKS dalam meningkatkan hasil belajar siswa. Secara kualitatif, belajar dengan menggunakan LKS berbasis doscovery learning direspon dengan baik oleh siswa, hal ini dibuktikan dengan antusias siswa saat pembelajaran, menumbuhkan motivasi saat belajar dan materi yang 
terdapat dalam LKS mudah dipahami oleh siswa. Dengan demikian, LKS yang dihasilkan dalam tahap penelitian pertama ini dapat dilanjutkan pada penelitian tahap berikutnya dengan melakukan revisi berdasar temuan lapangan penelitian dengan tetap memperhatikan saran validator berikutnya.

Saran bagi guru hendaknya mereka dapat mengembangkan LKS dengan berbagai variasi perlakuan, hal ini didasarkan pada banyaknya temuan penelitian yang mendukung pemanfaatan LKS pada peningkatan kualitas proses dan hasil pembelajaran. Bagi peneliti berikutnya dapat menindaklanjuti penggunaan LKS yang telah dikembangkan ini pada uji coba kelas yang lebih besar sebagai mana langkah yang dikembangkan oleh dari Borg and Gall, yakni menuju langkah keenam sampai dengan langkah kesepuluh.

\section{REFERENSI}

Borg, W.R. \& Gall, M.D. (1983). Educational research: an introduction, fifth edition. New York: Longman.

Celikler, D., \& Aksan, Z. (2012). The effect of the use of worksheets about aqueous solution reactions on pre-service elementary science teachers' academic success. Procedia-Social and Behavioral Sciences, 46, 4611-4614.

Fannie, R. D., \& Rohati, R. (2014). Pengembangan lembar kerja siswa (LKS) berbasis POE (predict, observe, explain) pada materi program linear kelas XII SMA. Sainmatika: Jurnal Sains dan Matematika Universitas Jambi, 8(1), 221053.

Irfana, S., Yulianti, D., \& Wiyanto, W. (2019). Pengembangan lembar kerja peserta didik berbasis science, technology, engineering, and mathematics untuk meningkatkan kemampuan berpikir kreatif peserta didik. UPEJ Unnes Physics Education Journal, 8(1), 83-89.

Hanim, F., Suyanti, R. D., \& Harahap, F. (2017). The effect of students' worksheet based on skill of science and motivation process toward learning outcomes at Grade 4 SDNegeri 164330 Tebingtinggi. IOSR Journal of Research $\mathcal{E}$ Method in Education (IOSR-JRME), 7(5), 57-61.

Kusumawati, M. A. S. (2017). Pengembangan LKS IPA berbasis pendekatan saintifik untuk siswa Kelas IV materi macam-macam energi. Skripsi, Program Studi PGSD, Jurusan Ilmu Pendidikan, FKIP, Universitas Sanata Dharma Yogyakarta.

Mulyatiningsih, E. (2012). Metode penelitian terapan bidang pendidikan. Bandung: Alfabeta.

Peraturan Menteri Pendidikan dan Kebudayaan Republik Indonesia Nomor 37 Tahun 2018 tentang Perubahan Atas Peraturan Menteri Pendidikan Dan Kebudayaan Nomor 24 Tahun 2016 Tentang Kompetensi Inti dan Kompetensi Dasar Pelajaran Pada Kurikulum 2013 Pada Pendidikan Dasar dan Pendidikan Menengah

Peraturan Menteri Pendidikan dan Kebudayaan Nomor 20 Tahun 2016 tentang Standar Kompetensi Lulusan Pendidikan Dasar dan Menengah.

Peraturan Menteri Pendidikan dan Kebudayaan Nomor 21 Tahun 2016 tentang Standar Isi Pendidikan Dasar dan Menengah.

Peraturan Menteri Pendidikan dan Kebudayaan Nomor 65 Tahun 2013 tentang Standar Proses Pendidikan Dasar dan Menengah.

Pertiwi, R. S., Abdurrahman, A., \& Rosidin, U. (2017). Efektivitas LKS STEM untuk melatih keterampilan berpikir kreatif siswa. Jurnal Pembelajaran Fisika, 5(2), 11-19.

Prastowo, A. (2014). Pengembangan bahan ajar tematik. Jakarta: PrenadaMedia Group.

Sari, M. (2013). Problematika pembelajaran sains ditinjau dari aspek guru. Al-Ta lim Journal, 20(1), 346-356. 


\section{MADRASAH}

Jurnal Pendidikan dan Pembelajaran Dasar

p ISSN: 1979-5599 | e ISSN: 2502-194X

P a g e | 25

Shalikhah, M. D. (2015). Pengembangan Lembar Kerja Siswa (LKS) Berbasis Pendekatan Scientific untuk Melatih Ketrampilan Sains Siswa Kelas IV SD/MI. Tesis, Program Studi PGMI Program Pascasarjana Universitas Islam Negeri Sunan Kalijaga Yogyakarta.

Sudjana, N. (1995). Penilaian hasil proses belajar mengajar. Bandung: PT Remaja Rosdakarya.

Sukamti dan Untari, E. (2018). Pelaksanaan Pembelajaran IPA SD Kurikulum 2013 pada Kelas Atas di Sekolah Dasar Kota Blitar. http://lib.um.ac.id/wpcontent/uploads/2018/01/PelaksanaanPembelajaran-IPA-.pdf

Susilowati. (2014). Pembelajaran IPA pada Kurikulum 2013. Makalah disampaikan dalam program Pengabdian pada Masyarakat (PPM) "Workshop Penguatan Content Knowledge Keintegrasian Materi IPA SMP Kelas VII untuk Mengatasi Hambatan Guru IPA dalam Implementasi Kurikulum 2013 ", Universitas Negeri Yogyakarta, tanggal 24 Agustus.

Syawaludin, A., Poerwanti, J. I. S., dan Hadiyah. (2017). Pengembangan Lembar Kerja Siswa (LKS) IPA Berbasis Model Predict, Observe, Explain (Poe) Di Sekolah Dasar. Didaktika Dwija Indria, 5(1).

Vallusova, A. (2013). Worksheet as a method helping students to apply theory, 83-92. In book: inovating teaching and learning. L'udmila Adamova and Petra Murarikova (Eds.), Toronto: Budrich UniPress, DOI: $10.2307 /$ j.ctvddzm4h.11

Wahidmurni, W. (2017). Metodologi pembelajaran IPS: pengembangan standar proses pembelajaran IPS di sekolah/madrasah. Yogyakarta: Ar-RuzzMedia.

Winahyu, S. E., Kartini, H., \& Bintartik, L. (2017). Pengembangan LKS Berbasis Saintifik untuk Menumbuhkan Karakter Ilmiah pada Siswa SD. Sekolah Dasar: Kajian Teori dan Praktik Pendidikan, 25(1), 74-81.

Windiastuti, E. P., Suyono, S., \& Kuntjoro, S. (2018). Development of the Guided Inquiry Student Worksheet for Biology Grade 11th Senior High School. JPPS (Jurnal Penelitian Pendidikan Sains), 7(2), 1513-1518. 